\title{
Pengembangan model pembelajaran creative problem solving terintegrasi TPACK untuk meningkatkan kemampuan pemecahan masalah
}

\author{
Edy Waluyo ${ }^{\text {a, } * \text {, Nuraini }}{ }^{\text {b }}$ \\ Program Studi Pendidikan Matematika, Universitas Hamzanwadi \\ Jl. TGKH. M. Zainuddin Abdul Majid, No. 132 Pancor, 83612, Selong, Lombok Timur, NTB, Indonesia \\ E-mail: ${ }^{a}$ edywaluyo@ hamzanwadi.ac.id, ${ }^{\mathrm{b}}$ nuraeni@hamzanwadi.ac.id \\ * Coresponding Author
}

\section{ARTICLE INFO}

\section{Article history}

Received: 11 Mar 2021

Revised: 23 Nov 2021

Accepted: 29 Nov 2021

\section{Keywords}

Creative problem solving, pemecahan masalah, TPACK

Creative problem solving, problem solving, TPACK

\section{Scan me:}

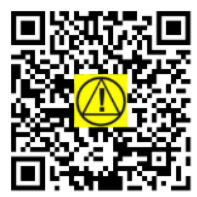

\begin{abstract}
Guru perlu menerapkan model pembelajaran yang mampu mengembangkan kemampuan berpikir tingkat tinggi dan kemampuan pemecahan masalah. Penelitian ini bertujuan untuk mengembangkan model pembelajaran Creative Problem Solving (CPS) terintegrasi TPACK untuk mengembangkan dan meningkatkan kemampuan siswa dalam pemecahan masalah. Penelitian ini merupakan penelitian pengembangan dengan model pengembangan Borg \& Gall. Sampel penelitian ini adalah siswa kelas VII Sekolah Menengah Pertama di Lombok Timur yang berjumlah 30 siswa, yang terdiri dari 12 siswa laki laki dan 18 siswa perempuan. Instrumen yang digunakan untuk mengumpulkan data meliputi pedoman validasi desain pembelajaran CPS terintegrasi TPACK, angket kepraktisan dan tes kemampuan pemecahan masalah pada materi geometri. Analisis data yang digunakan dalam penelitian ini menggunakan analisis deskriptif. Berdasarkan analisis validasi, produk yang dikembangkan termasuk kategori valid yang ditunjukkan oleh skor rata-rata validasi produk oleh 3 ahli yaitu ahli bahasa, ahli materi dan ahli teknologi pembelajaran berturut turut 79,4; 79,9; dan 80,8. Begitu pula dari segi kepraktisan, produk yang dikembangkan juga tergolong praktis dengan rata-rata skor kepraktisan 82,67 . Produk juga tergolong efektif dengan persentase keefektifan sebesar $86,67 \%$. Produk yang dikembangkan mempunyai efek potensial dalam kategori tinggi untuk meningkatkan kemampuan siswa dalam pemecahan masalah matematika dengan $N$-Gain sebesar 0,81 .
\end{abstract}

Teachers need to apply teaching models that enable students to develop high order thinking skills and student problem-solving skills. This research aims to develop TPACK's integrated Creative Problem Solving (CPS) teaching model to improve students' ability to solve problems. This research was developmental research applying Borg \& Gall development model. The sample was 30 grade VII students of a State Junior High School, in Lombok Timur, Indonesia, consisting of 12 male and 18 female students. The instruments used to collect the data include TPACK integrated CPS learning design validation guidelines, practicality questionnaires, and troubleshooting tests on geometric materials. The data analysis used descriptive analysis. Based on the validation analysis, the developed model was in a valid category as indicated by the average score of product validation by three experts: a linguist, materials expert, and learning technology expert, with scores of 79.4, 79.9, and 80.8 consecutively. Similarly, in terms of practicality, the developed model is also relatively practical with an average practicality score of 82.67 . The model is also classified as effective, with an effectiveness percentage of $86.67 \%$. It has a potential effect in the high category to improve students' ability to solve mathematic problems with an $\mathrm{N}$ gain of 0.81 .

This is an open access article under the CC-BY-SA license.

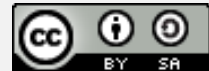


How to Cite: Waluyo, E., \& Nuraini, N. (2021). Pengembangan model pembelajaran creative problem solving terintegrasi TPACK untuk meningkatkan kemampuan pemecahan masalah. Jurnal Riset Pendidikan Matematika, 8(2), 191-205. https://dx.doi.org/10.21831/jrpm.v8i2.39354

\section{PENDAHULUAN}

Pada pembelajaran abad ke-21 saat ini, perlu dilakukan pembelajaran demikian sehingga setiap siswa memiliki kemampuan berpikir tingkat tinggi, kemampuan memecahkan masalah, kemampuan berkomunikasi, dan kemampuan berpikir matematis untuk dapat menghadapi tantangan global (NCTM, 2000). Pendidikan formal di Indonesia saat ini masih belum menekankan pada bagaimana mengembangkan kemampuan berpikir tingkat tinggi dalam menyelesaikan masalah matematika (Yanti, 2019, p. 73). Fasilitasi guru kepada siswa dalam menggali ide berkaitan dengan materi yang dibelajarkan belum dilakukan secara memadai (Mahmudi, 2009, p. 3). Menurut studi TIMSS pada tahun 2015, menyebutkan bahwa kemampuan matematika siswa Indonesia di bidang matematika masih jauh dibandingkan negara lain yaitu berada pada rangking 44 dari 49 negara (Mullis, 2016). Begitu pula dari hasil survey PISA pada tahun 2015, kemampuan pemecahan masalah siswa SD dan SMP di Indonesia masih rendah (OECD, 2016). Menghadapi permasalahan tersebut perlu dilakukan pembelajaran yang mampu melibatkan siswa secara aktif dalam pembelajaran sehingga siswa mampu menggali ide dengan memanfaatkan teknologi sehingga diperoleh konsep dan strategi dalam menyelesaikan masalah matematika (Khaulah, 2018, p. 76; Siswono, 2008, p. 62).

Hasil wawancara terhadap guru matematika dan siswa sekolah menengah pertama yang dilakukan peneliti menunujukkan bahwa bahwa (1) proses pembelajaran yang dilakukan guru masih bersifat konvensional dan belum berpusat pada siswa, guru belum menekankan pada bagaimana mengembangkan kemampuan pemecahan masalah pada siswa, hanya memberi contoh soal dilanjutkan dengan latihan soal; (2) Kesadaran akan pentingnya pemanfaatan teknologi oleh guru dan siswa dalam pembelajaran masih rendah; (3) Sekolah perlu menyiapkan sarana seperti jaringan internet dan laboratorium komputer yang menunjang pembelajaran. Berdasarkan angket yang diberikan kepada 20 siswa kelas VII Sekolah Menengah Pertama terhadap pembelajaran yang diperoleh menunjukkan bahwa (1) pembelajaran yang diperoleh pada umumnya belum menyenangkan dan membosankan dan terkesan bahwa matematika meupakan pelajaran yang sulit dengan persentase sebesar 75\%; (2) dalam pembelajaran guru belum menggunakan teknologi yang memadai dalam pembelajaran matematika; (3) pemanfaatan teknologi dalam pembelajaran masih rendah dengan persentase sebesar 80\%; (4) Guru belum memilih dan menerapkan pembelajaran yang inovatif dalam pembelajaran sehingga kemampuan pemecahan masalah siswa belum dikembangkan dengan persentase sebesar $75 \%$.

Mengembangkan kemampuan pemecahan masalah merupakan bagian dalam mengembangkan kemampuan berpikir tingkat tinggi siswa (Waluyo, 2020, p. 359). Dalam pembelajaran matematika, mengembangkan kemampuan pemecahan masalah merupakan aktivitas yang sulit dilakukan siswa (Khatimah \& Sugiman, 2019, p. 2). Dalam pemecahan masalah, siswa dituntut untuk berpikir sehingga dapat menemukan berbagai cara untuk masalah matematika nyata yang dihadapi. Endah (2019, p. 209) mengemukakan bahwa kemampuan pemecahan masalah merupakan kemampuan dalam menggunakan pengetahuan yang dimiliki seseorang untuk menemukan jawaban terhadap masalah yang dihadapi. Pemecahan masalah merupakan aktivitas intelektual dalam menemukan solusi atau penyelesaian dari masalah dengan melibatkan pengetahuan, wawasan dan pengalaman (Maimunah, 2016, p. 20). Pemecahan masalah sebagai suatu kemampuan dalam menggunakan pengetahuan yang dimiliki atau diketahui sebelumnya untuk menyelesaikan masalah (Ulya, 2016, p. 91). Rahmani (2018, p. 20) menyatakan bahwa melalui kemampuan pemecahan masalah siswa dapat menemukan berbagai kemungkinan penyelesaian masalah melalui keterkaitan berbagai bidang ilmu yang telah dipelajarinya.

Untuk meningkatkan kemampuan memecahkan masalah perlu dikembangkan keterampilan memahami masalah, membuat model matematika, menyelesaikan masalah dan menafsirkan solusinya (Hidayat, 2018, p. 110). Dengan kemampuan pemecahan masalah, siswa dapat menyelesaikan permasalahan matematika berupa soal cerita dan soal matematika yang tidak rutin yang berkaitan dengan kehidupan sehari hari (Andayani \& Lathifah, 2019, p. 2). Siswa dalam melakukan pemecahan masalah, langkah-langkah yang dilalui meliputi: (1) memahami masalah; (2) merencanakan penyelesaian masalah; (3) menyelesaikan masalah, dan (4) melakukan pengecekan kembali semua langkah yang telah dikerjakan (Nur, 2018, p. 140). Sementara itu, kemampuan pemecahan masalah matematika memiliki indicator sebagai berikut: (1) mampu melakukan identifikasi unsur yang 
diketahui, ditanyakan, dan syarat cukup yang diperlukan, (2) mampu merumuskan masalah atau model matematika, (3) mampu memilih dan menerapkan strategi yang sesuai untuk menyelesaikan masalah, (4) mampu memberikan penjelasan terhadap hasil yang diperoleh sesuai permasalahan, dan (5) mampu menggunakan konsep matematika yang ditemukan (NCTM, 2000).

Berdasarkan hal tersebut di atas, salah satu strategi pembelajaran yang perlu dilalukan guru yang mampu membelajarkan siswa secara aktif dan berpotensi untuk meningkatkan kemampuan pemecahan masalah matematika adalah model Creative Problem Solving. Creative problem Solving dianggap efektif dan mampu mengembangkan kemampuan pemecahan masalah matematika siswa dalam menyelesaikan masalah nyata yang dhadapi sehari-hari (Ismiyanto, Syafii, \& Syakir, 2010, p. 104). Creative Problem Solving adalah kemampuan berpikir yang dimiliki siswa dan berfungsi meningkatkan kemampuan berpikir tingkat tinggi dalam menyelesaikan masalah (Puccio, 2005, p. 65). Penggunaan Creative Problem Solving yang memfasilitasi proses problem solving terhadap permasalahan tertentu akan menyiapkan ruang untuk peningkatan kreativitas dalam memecahkan masalah (Adams, 2010, p. 6). Model pembelajaran Creative Problem Solving adalah suatu model pembelajaran yang melakukan pemusatan pada pembelajaran dan keterampilan memecahkan masalah, yang diikuti dengan penguatan keterampilan (Effendi \& Fatimah, 2019; Hariawan, 2014; Nur, 2017; Paryanto \& Kurniasih, 2020; Nursiami, 2015; Sugianto, 2019; Turmuzi, 2018). Pembelajaran dengan model Creative Problem Solving ini memberikan kesempatan kepada guru untuk memotivasi, mendorong dan mengoptimalkan perkembangan pengetahuan satu sama lain siswa, dan untuk menguasai keterampilan-keterampilan yang disampaikan guru (Bahrudin, 2020, p. 537). Dengan demikian siswa lebih bebas atau leluasa untuk bepikir, merespons dan saling membantu (Pramestika, 2020, p. 362). Pada Creative Problem Solving, untuk menyelesaikan masalah baru yang dihadapi, siswa memerlukan pengalamanan sebelumya yang digunakan dalam meyelesaikan masalah. Berdasarkan pengalaman sebelumnya, ketika siswa dihadapkan pada suatu permasalahan baru, siswa dapat memilih dan mengembangkan ide yang diperoleh sebelumnya, menggunakan kemampuan memecahkan masalah serta mengembangkan proses berpikir tingkat tinggi (Pepkin, 2004, p. 1).

Pembelajaran dengan Creative Problem Solving mengikuti langkah-langkah sebagai berikut: (1) orientasi pada masalah, yakni guru menjelaskan masalah yang diajukan kepada siswa untuk dapat dipahami serta bagaimana penyelesaiannya; (2) siswa mengungkapkan pendapatnya tentang berbagai kemungkinan strategi yang dapat digunakan untuk menyelesaikan masalah yang diberikan guru; (3) siswa berdiskusi secara kelompok untuk memilih dan menentukan srategi yang sesuai untuk menyelesaikan masalah; (4) implementasi atau penerapan, siswa memilih strategi yang tepat untuk menyelesaikan masalah yang diberikan guru dan menerapkannya sehingga ditemukan penyelesaian dari masalah tersebut (Muslich, 2007). Huda (2014, p. 236) mengemukakan bahwa langkah-langkah model pembelajaran Creative Problem Solving yaitu (1). Objective Finding, yaitu siswa dibagi ke dalam kelompok-kelompok untuk mendiskusikan situasi permasalahan yang diajukan guru; (2). Fact Finding, yaitu siswa melakukan brainstorming semua fakta yang berkaitan dengan masalah; (3) Problem Finding, yaitu guru menjelaskan masalah yang diberikan; (4) Idea Finding, yaitu penemuan gagasan sebagai solusi penyelesaian masalah; (5) Solution Finding, yaitu mengevaluasi berbagai gagasan yang ditemukan siswa yang dimungkinkan dapat digunakan sebagai jawaban untuk menyelesaikan permasalahan; (6) Acceptance Finding, yaitu siswa menerapkan gagasan yang ditemukan dan dipilih melalui proses berpikir untuk menyelesaikan masalah. Mengacu pada langkah-langkah yang diuraikan di atas, pembelajaran dengan Creative Problem Solving mempunyai potensi untuk mengembangkan kemampuan berpikir tingkat tinggi siswa dalam menyelesaikan permasalahan yang diberikan guru. (Septian, 2019, p. 182).

Perkembangan teknologi informasi dan komunikasi telah memberikan pengaruh besar terhadap proses pembelajaran abad 21 dan mendorong guru untuk memiliki pengetahuan terkait teknologi informasi dan komunikasi. Menghadapi perkembangan teknologi pada pembelajaran abad 21 saat ini, guru dituntut untuk memiliki pengetahuan Technological, Pedagogical, Content Knowledge (TPACK) yang mampu mengintegrasikan teknologi dalam pembelajaran apalagi pembelajaran di sekolah saat ini harus mengikuti adaptasi kebiasaan baru akibat pandemi covid-19. Technological pedagogical content knowledge (TPACK) merupakan salah suatu jenis pengetahuan baru yang harus dikuasi guru untuk dapat mengintegrasikan teknologi dengan baik dalam pembelajaran (Mishra \& Koehler, 2006, p. 1024). TPACK merupakan transformasi pengetahuan, konten dan pengetahuan pedagogis menjadi jenis pengetahuan berbeda yang digunakan untuk mengembangkan dan melaksanakan strategi pengajaran 
(Tuithof, 2021, p. 5). Technological Pedagogical Content Knowledge merupakan pengetahuan tentang bagaimana berbagai teknologi dapat digunakan dalam pembelajaran dan penggunaan teknologi tersebut mampu mengubah cara guru mengajar (Farikah, 2020, p. 194). Dalam pembelajaran, guru harus mempunyai kompetensi yang diperlukan dalam mengintegrasikan teknologi secara tepat dan efektif (Akturk, 2019, p. 284). TPACK adalah wadah yang merupakan integrasi dari teknologi, pedagogi, dan pengetahuan materi atau konten yang saling mempengaruhi dalam proses pembelajaran (Rahmadi, 2020, p. 114).

Integrasi teknologi dalam pelaksanaan pembelajaran yang dilakukan guru merupakan faktor utama dalam menggunakan pendekatan TPACK (Malik, 2018, p. 501). Koehler, Mishra, \& Cain (2013, p. 66) menyatakan bahwa TPACK merupakan kerangka kerja yang digunakan untuk menganalisis integrasi teknologi dalam pembelajaran yang dilakukan guru. Berdasarkan uraian di atas, TPACK merupakan kerangka dalam mengintegrasikan antara penguasaan teknologi dan kemampuan pedagogik dalam memilih strategi pembelajaran yang dilakukan guru dalam membelajarkan konten tertentu kepada siswa. Dengan demikian, TPACK merupakan pengetahuan yang harus dimiliki seorang guru tentang kapan dan bagaimana menggunakan teknologi dalam pembelajaran materi tertentu. Oleh karena itu, guru dituntut untuk meningkatkan pengetahuan dan keterampilan mereka dalam bidang studi tertentu dan mampu mengintegrasikan dengan teknologi dalam framework atau model pembelajaran tertentu. Disamping itu, guru harus dapat menggunakan teknologi yang tepat pada pedagogik yang sesuai untuk konten yang spesifik dengan baik.

Model pembelajaran Creative Problem Solving terintegrasi TPACK merupakan model pembelajaran Creative Problem Solving dimana dalam setiap langkah pembelajaran diintegrasikan dengan pemanfaatan teknologi seperti menggunakan LCD, android, aplikasi google drive, power point, dan sebagainya. Beberapa peneliti telah melakukan pengembangan desain pembelajaran berbasis CPS dengan menggunakan pendekan TPACK. Manurung $(2015$, p. 7$)$ dalam penelitiannya menunjukkan bahwa kemampuan berpikir kritis siswa yang memperoleh pembelajaran melalui penerapan model CPS dengan menggunakan Autograph lebih baik dari siswa yang memperoleh pembelajaran hanya melalui penerapan model CPS saja. Partayasa (2020, p. 168) dalam penelitiannya yang berjudul Pengaruh Model Creative Problem Solving (CPS) Berbantuan Video Pembelajaran Terhadap Kemampuan Pemecahan Masalah Ditinjau Dari Minat menunjukkan bahwa penerapan model CPS berbantuan video pembelajaran lebih baik dari pada pembelajaran konvensional. Sehingga, model CPS berbantuan video pembelajaran berkontribusi positif terhadap kemampuan pemecahan masalah matematika siswa.

Berdasarkan hasil penelitian tersebut di atas, peneliti mengembangkan model pembelajaran Creative Problem Solving terintegrasi TPACK dengan langkah langkah meliputi: (1) orientasi masalah nyata yaitu pemberian penjelasan kepada siswa tentang masalah yang diajukan, melalui aplikasi google drive; (2) pengungkapan pendapat, yakni siswa diberikan kebebasan dalam menyampaiakan ide dan gagasannya berkaitan dengan semua strategi yang mungkin untuk menyelesaikan masalah yang diberikan guru dengan menggali informasi melalui internet dan android mereka; (3) evaluasi, yaitu siswa melakukan diskusi secara berkelompok untuk mendiskusikan strategi yang sesuai untuk menyelesaikan masalah dengan salah seorang siswa mendokumentasikan dengan android mereka; (4) implementasi, yaitu siswa menerapkan strategi yang dipilih sebagai hasil diskusi untuk menyelesaikan masalah dengan mengakses informasi yang dibutuhkan dengan android mereka; (5) presentasi, yakni setiap perwakilan kelompok mempresentasikan hasil diskusinya dengan kelompok lain memberikan tanggapan; (6) refleksi, yakni guru melakukan evaluasi terhadap semua kegiatan yang dilakukan siswa dan bersama siswa menarik kesimpulan. Penelitian ini bertujuan untuk mengembangkan strategi pembelajaran Creative Problem Solving dengan mengintegrasikan TPACK untuk mengembangkan dan meningkatkan kemampuan pemecahan masalah matematika siswa sekolah menengah pertama. Melalui penerapan pembelajaran dengan integrasi teknologi seperti pemanfaatan android, software dan aplikasi lainnya dalam pembelajaran Creative Problem Solving diharapkan dapat meningkatkan kemampuan pemecahan masalah matematika siswa Sekolah Menengah Pertama.

\section{METODE}

Jenis penelitian yang digunakan dalam penenlitian ini adalah penelitian pengembangan model Borg\& Gall dengan langkah langkah pengembangan (1) need assessment (analisis kebutuhan), (2) desain produk, (3) pengembangan produk, (4) implementasi dan evaluasi produk (Borg \& Gall, 2007, 
p. 775). Analisis kebutuhan dilakukan dengan wawancara terbuka kepada guru matematika dan memberikan angket kepada siswa tentang perasaan siswa dalam mengikuti pembelajaran oleh guru matematika.Wawancara terhadap guru matematika terkait dengan strategi pembelajaran yang digunakan dan integrasi teknologi terdiri dari 5 pertanyaan. Angket tentang perasaan siswa setelah mengikuti pembelajaran terdiri dari 10 pertanyaan. Subjek uji coba penelitian ini adalah siswa kelas VII SMP dengan jumlah 30 siswa yang terdiri 12 siswa laki laki dan 18 siswa perempuan yang diambil secara cluster random sampling. Sintaks model pembelajaran Creative Problem Solving terintegrasi TPACK dikembangkan dengan langkah langkah seperti Tabel 1.

Tabel 1. Sintak model pembelajaran Creative Problem Solving terintegrasi TPACK

\begin{tabular}{|c|c|c|c|}
\hline No & Fase & Kegiatan guru & Kegiatan siswa \\
\hline 1 & $\begin{array}{l}\text { Orientasi pada } \\
\text { masalah }\end{array}$ & $\begin{array}{l}\text { Guru membagi kelompok yang } \\
\text { terdiri dari 3-5 siswa, menjelaskan } \\
\text { kepada siswa tentang masalah } \\
\text { yang diajukan. }\end{array}$ & $\begin{array}{l}\text { Memperhatikan penjelasan guru tentang } \\
\text { masalah yang akan diselesaikan. }\end{array}$ \\
\hline 2 & $\begin{array}{l}\text { Pengungkapan } \\
\text { pendapat }\end{array}$ & $\begin{array}{l}\text { Guru memfasilitasi siswa dalam } \\
\text { menggali ide dan gagasan. }\end{array}$ & $\begin{array}{l}\text { Siswa dibebaskan untuk mengungkapkan } \\
\text { pendapatnya tentang berbagai macam } \\
\text { strategi penyelesaian masalah dengan } \\
\text { menggali informasi melalui internet dan } \\
\text { android mereka. }\end{array}$ \\
\hline 3 & Evaluasi & $\begin{array}{l}\text { Guru membimbing siswa dalam } \\
\text { penyelesaian masalah }\end{array}$ & $\begin{array}{l}\text { Setiap kelompok mendiskusikan } \\
\text { pendapat atau strategi mana yang cocok } \\
\text { untuk menyelesaikan masalah dengan } \\
\text { salah seorang siswa mendokumentasikan } \\
\text { dengan android mereka. }\end{array}$ \\
\hline 4 & Implementasi & $\begin{array}{lrr}\text { Guru } & \text { memfasilitasi } & \text { secara } \\
\text { individu dan } & \text { kelompok } & \text { dalam } \\
\text { menemukan } & & \text { penyelesaian } \\
\text { masalah. } & & \end{array}$ & $\begin{array}{l}\text { Siswa menentukan strategi yang dapat } \\
\text { cocok untuk menyelesaikan masalah dan } \\
\text { menemukan penyelesaian dari masalah } \\
\text { dengan mengakses informasi yang } \\
\text { dibutuhkan dengan android mereka. }\end{array}$ \\
\hline 5 & Presentasi & $\begin{array}{lrr}\text { Guru membimbing } & \text { dan } \\
\text { mengarahkan } & \text { siswa } & \text { dalam } \\
\text { melalukan presentasi } & \text { dan } \\
\text { memberikan penguatan. } & \end{array}$ & $\begin{array}{lrr}\text { Perwakilan setiap } & \text { kelompok } \\
\text { mempresentasikan hasil } & \text { pemecahan } \\
\text { masalah yang dilakukan, } & \text { sedangkan } \\
\text { kelompok lainnya } & \text { memberikan } \\
\text { tanggapan. } & & \end{array}$ \\
\hline 6 & Refleksi & $\begin{array}{l}\text { Guru melalukan evaluasi terhadap } \\
\text { seluruh kegiatan pemecahan } \\
\text { masalah yang dilakukan siswa dan } \\
\text { bersama siswa menarik } \\
\text { kesimpulan untuk mendapatkan } \\
\text { konsep yang berkaitan dengan } \\
\text { masalah yang dipecahkan siswa. }\end{array}$ & $\begin{array}{l}\text { Siswa menarik kesimpulan berdasarkan } \\
\text { permasalahan yang diselesaikan atas } \\
\text { bimbingan guru. }\end{array}$ \\
\hline
\end{tabular}

Instrumen penelitian yang digunakan dalam penelitian ini meliputi (1) pedoman validasi produk pembelajaran, (2) pedoman kepraktisan keterlaksanaan pembelajaran dan (3) tes kemampuan pemecahan masalah. Pedoman validasi produk pembelajaran yang dikembangkan memuat indikator pengukuran antara lain: (a) indikator perumusan tujuan , (b) indikator isi, (c) indikator bahasa yang digunakan, dan (d) indikator waktu. Sementara itu, pedoman kepraktisan keterlaksanaan produk yang dikembangkan memuat indikator (a) perasaan senang siswa terhadap proses pembelajaran, (b) penilaian kebaruan produk yang dikembangkan dalam pembelajaran, (c) minat siswa dalam mengikuti pembelajaran menggunakan produk yang dikembangkan. Instrumen tes kemampuan pemecahan masalah yang dikembangkan berupa tes essai dengan indikator: 1) kemampuan siswa memahami masalah; 2) kemampuan siswa dalam memilih dan menyususn strategi penyelesaian masalah; 3) kemampuan siswa dalam menyelesaikan permasalahan sesuai strategi peyelesaian yang telah dipilih dan 
disusun, dan 4) ketelitian siswa dalam memeriksa kembali penyelesaian yang telah dilakukan (Winarti, 2017). Sementara itu, produk berupa rancangan pembelajaran yang telah dikembangkan divalidasi oleh 3 orang ahli yaitu ahli materi, ahli teknologi pembelajaran, dan ahli bahasa. Untuk mendapatkan produk yang valid, praktis, dan efektif dilakukan ujicoba lapangan.

Kualitas produk pengembangan berupa rancangan pembelajaran model pembelajaran Creative Problem Solving terintegrasi TPACK diukur berdasarkan validitas produk, kepraktisan produk dan efektivitas produk. Indikator validasi produk disajikan dalam Tabel 2 dan Tabel 3.

Tabel 2. Pedoman validasi produk yang dikembangkan oleh ahli materi

\begin{tabular}{ll}
\hline Aspek & Indikator \\
\hline Kesesuaian & $\begin{array}{l}\text { Tingkat kesesuaian rancangan pembelajaran dengan model yang dikembangkan } \\
\text { dengan kompetensi dasar dan indikator pencapaian kompetensi yang ada pada } \\
\text { kurikulum. } \\
\text { Kemudahan } \\
\text { Kelengkapan yang digunakan dalam mengembangkan produk dengan tingkat } \\
\text { pemahaman sulit, sedang atau mudah oleh guru. } \\
\text { Kelengkapan materi dan pemilihan aplikasi teknologi (google drive, power } \\
\text { koint, android, dll). } \\
\text { Kejelasan deskripsi dan pengaturan sistematis materi dalam model } \\
\text { pembelajaran. }\end{array}$ \\
\hline
\end{tabular}

Tabel 3. Pedoman validasi produk oleh ahli teknologi pembelajaran

\begin{tabular}{ll}
\hline Aspek & Indikator \\
\hline Kesesuaian & $\begin{array}{l}\text { Produk yang dikembangkan mengintegrasikan teknologi yang sesuai dengan } \\
\text { materi pembelajaran yang dibelajarkan guru. }\end{array}$ \\
Kemudahan & $\begin{array}{l}\text { Produk yang dikembangkan menggunakan teknologi yang mudah digunakan } \\
\text { guru dan siswa. }\end{array}$ \\
Komunikatif & $\begin{array}{l}\text { Bahasa yang digunakan mudah dimengerti dan pemilihan teknologi untuk } \\
\text { pembelajaran yang mudah digunakan oleh siswa. }\end{array}$ \\
\hline
\end{tabular}

Produk yang dikembangkan berupa rancangan pembelajaran dengan model Creative Problem Solving teritegrasi TPACK dikatakan valid jika produk yang dikembangkan sesuai dengan setiap aspek dengan indikator yang ditetapkan untuk setiap aspek. Kriteria kevalidan dari model pembelajaran yang dikembangkan yaitu model pembelajaran Creative Problem Solving terintegrasi TPACK digunakan kriteria seperti Tabel 4 (Waluyo, 2020, p. 361).

Tabel 4. Kriteria kevalidan model pembelajaran yang telah dikembangkan

\begin{tabular}{ll}
\hline Skor interval & Kriteria kevalidan \\
\hline$X>85$ & Sangat valid \\
$70<X \leq 85$ & Valid \\
$X \leq 70$ & Tidak valid \\
\hline
\end{tabular}

Kepraktisan produk yang dikembangkan berupa rancangan pembelajaran Creative Problem Solving teritegrasi TPACK diuji berdasarkan (1) penilaian kepraktisan produk oleh ahli, (2) besarnya respon guru setelah melaksanaan pembelajaran Creative Problem Solving terintegrasi TPACK, dengan kriteria seperti Tabel 5.

Tabel 5. Kriteria kepraktisan model pembelajaran yang telah dikembangkan

\begin{tabular}{ll}
\hline Skor interval & Kriteria \\
\hline$X>85$ & Sangat praktis \\
$70<X \leq 85$ & Praktis \\
$X \leq 70$ & Tidak Praktis \\
\hline
\end{tabular}


Sementara itu untuk menguji keefektifan produk yang dikembangkan berupa rancangan pembelajaran Creative Problem Solving terintegrasi TPACK dilakukan dengan melakukan analisis terhadap skor hasil tes kemampuan pemecahan masalah siswa setelah mendapatkan pembelajaran. Indikator efektivitas produk yang ditetapkan yaitu terdapat minimal $85 \%$ dari seluruh siswa yang mengikuti tes hasil belajar terkait pemecahan masalah matematika mendapatkan skor minimal 75. Sementara itu untuk menguji efek potensial produk yang telah dikembangkan dalam meningkatkan kemampuan pemecahan masalah matematika siswa dilakukan dengan menghitung nilai $\mathrm{N}$-Gain dengan menghitung selisih antara skor postes dengan pretes tentang kemampuan pemecahan masalah matematika siswa.

\section{HASIL DAN PEMBAHASAN}

\section{Analisis kebutuhan}

Sebelum dilakukan penelitian sebagai dasar untuk mengembangkan produk, peneliti melakukan analisis kebutuhan dengan melakukan wawancara kepada guru matematika Sekolah Menegah Pertama terkait dengan penerapan strategi pembelajaran yang digunakan serta memberikan angket kepada siswa tentang perasaan siswa setelah mengikuti pembelajaran matematika. Hasil wawancara terhadap 3 guru matematika dapat disimpulkan bahwa (1) sebagian besar proses pembelajaran yang dilakukan masih bersifat konvensional dan belum berpusat pada siswa, dominasi guru dalam pembelajaran sangat tinggi, kemampuan berpikir siswa belum dikembangkan secara memadai dan guru lebih banyak memberikan contoh dan latihan soal; (2) Dalam pembelajaran, guru belum mengintegrasikan teknologi dalam membelajarkan konsep tertentu seperti memanfaatkan laptop, LCD, aplikasi google drive dan lainnya mengikuti tuntutan pembelajaran saat ini; (3) Dalam pembelajaran, sekolah perlu mempersiapkan fasilitas pendukung yang berkaitan dengan pemanfaatan teknologi seperti laptop, LCD dan jaringan internet yang memadai dalam mengintegrasikan teknologi dalam pembelajaran; (4) Guru mengharapkan adanya dukungan dari sekolah untuk meningkatkan pengetahuannya dibidang teknologi dan informasi sebagai bagian dari kompetensi yang dibutuhkan dalam melaksanakan pembelajaran saat ini.

Sementara itu, berdasarkan angket yang diberikan kepada 20 siswa kelas VII Sekolah Menengah Pertama terhadap pembelajaran yang diperoleh menunjukkan bahwa (1) pembelajaran yang diperoleh pada umumnya belum menyenangkan, membosankan, dan terkesan bahwa matematika masih dianggap sebagai salah satu pelajaran yang sulit dan menakutkan dengan persentase sebesar 75\%; (2) dalam pembelajaran, upaya guru untuk mengembangkan kemampuan pemecahan masalah matematika siswa belum optimal sehingga siswa bingung ketika menghadapi soal yang tidak rutin, yang memerlukan kemampuan berpikir tingkat tinggi dalam menyelesaikan masalah yang dihadapi; (3) dalam pembelajaran, guru dan siswa belum memanfaatkan teknologi yang memadai disebabkan ketersediaan teknologi yang dibutuhkan dalam pembelajaran di sekolah dengan persentase sebesar $80 \%$, hal ini disebabkan karena kurangnya fasilitas yang disiapkan oleh sekolah dan kemampuan ekonomi orang tua siswa untuk menyiapkan fasilitas seperti android; (4) Dalam pembelajaran, guru belum menggunakan stategi pembelajaran yang inovatif dan variatif sehingga pembelajaran bersifat momoton dengan persentase sebesar 75\%. Mengacu pada analisis kebutuhan di atas, perlu dikembangkan model pembelajaran yang mampu mengembangkan kemampuan berpikir tingkat tinggi dan kemampuan pemecahan masalah siswa dengan melibatkan siswa secara aktif dalam pembelajaran sehingga interaksi dua arah dalam pembelajaran dapat dilakukan.

\section{Tahap desain produk}

Produk yang dikembangkan berupa rancangan pembelajaran model Creative Problem Solving terintegrasi TPACK yaitu bagaimana dalam membelajarkan materi tertentu guru mampu mengintegrasikan antara teknologi dengan pengetahuan pedagogi yang dimiliki. Teknologi yang diintegrasikan berupa pemanfaatan teknologi informasi seperti LCD, laptop, aplikasi google drive dan aplikasi lainnya yang sesuai dengan pembelajaran yang digunakan. Tahapan pembelajaran model pembelajaran dengan Creative Problem Solving teritegrasi TPACK yang dikembangkan dimodifikasi dari model pengembangan yang dilakukan oleh Karen (2004, p. 2) dengan langkah : (1) orientasi masalah nyata yaitu guru memberikan penjelasan terhadap masalah yang diberikan kepada siswa melalui aplikasi google drive; (2) pengungkapan pendapat, yakni siswa diberikan kebebasan dalam menyampaiakan ide dan gagasannya berkaitan dengan semua strategi yang mungkin untuk 
menyelesaikan masalah yang diberikan guru dengan menggali informasi melalui internet dan android mereka; (3) evaluasi, yaitu siswa melakukan diskusi secara berkolempok untuk mendiskusikan strategi yang sesuai untuk menyelesaikan masalah dengan salah seorang siswa mendokumentasikan dengan android mereka; (4) implementasi, yaitu siswa menerapkan strategi yang dipilih sebagai hasil diskusi untuk menyelesaikan masalah dengan mengakses informasi yang dibutuhkan dengan android mereka; (5) presentasi, yakni setiap perwakilan kelompok mempresentasikan hasil diskusinya dengan kelompok lain memberikan tanggapan; (6) refleksi, yakni guru melakukan evaluasi terhadap semua kegiatan yang dilakukan siswa dan bersama siswa menarik kesimpulan.

\section{Tahap pengembangan dan evaluasi}

\section{Validitas produk}

Validasi produk berupa rancangan pembelajaran model Creative Problem Solving terintegrasi TPACK divalidasi oleh tiga orang ahli yaitu ahli materi pembelajaran, ahli teknologi pembelajaran, dan ahli bahasa menggunakan lembar validasi yang telah disusun dengan kriteria kevalidan yang ditetapkan. Hasil validasi dipergunakan untuk melakukan revisi terhadap produk yang dikembangkan berdasarkan masukan dan saran para ahli. Berdasarkan hasil analisis kevalidan diperoleh skor kevalidan produk seperti disajikan pada Tabel 6.

Tabel 6. Hasil validasi produk yang dikembangkan

\begin{tabular}{lccc}
\hline \multirow{2}{*}{ Komponen/Aspek } & \multicolumn{3}{c}{ Hasil validasi ahli } \\
\cline { 2 - 4 } & Ahli pertama & Ahli kedua & Ahli ketiga \\
\hline Identitas & 90 & 92 & 90 \\
Perumusan tujuan & 85 & 83 & 84 \\
Perumusan indikator & 75 & 78 & 73 \\
Kesesuaian materi & 80 & 78 & 78 \\
Strategi pembelajaran & 80 & 81 & 83 \\
Aktivitas pembelajaran & 85 & 83 & 84 \\
Pemilihaan teknologi & 75 & 78 & 79 \\
Integrasi teknologi & 70 & 72 & 76 \\
Penilaian & 76 & 81 & 82 \\
Penggunaan bahasa & 78 & 73 & 79 \\
Skor rata-rata & 79,4 & 79,9 & 80,8 \\
Kesimpulan & Valid & Valid & Valid \\
\hline
\end{tabular}

Mengacu pada hasil validasi oleh ahli pada Tabel 6 di atas, rata-rata skor validasi produk dari ketiga ahli berturut turut $79.4 ; 79.9$; dan 80.8 sehingga produk yang dikembangkan tergolong valid dan layak untuk digunakan.

\section{Revisi produk}

Meskipun menurut ahi, produk berupa rancangan pembelajaran berbasis Creativie Problem Solving teritegrasi TPACK memenuhi kriteria kevalidan dan layak dilanjutkan dengan uji coba lapangan, namun terdapat beberapa komponen yang perlu direvisi menurut ahli antara lain : 1) Aspek perumusan indikator, yaitu perlunya digunakan kata kerja operasional C4, C5, dan C6 yang mengukur kemampuan pemecahan masalah, 2) Aspek pemilihan teknologi, disarankan menggunakan aplikasi yang mudah digunakan oleh siswa, 3) Aspek bahasa, disarankan menggunakan bahasa yang mudah dipahami oleh siswa.

\section{Kepraktisan produk}

Kepraktisan produk berupa rancangan pembelajaran model pembelajaran Creative Problem Solving terintegrasi TPACK yang dikembangkan diuji berdasarkan skor kepraktisan oleh para ahli serta keterlaksanaan pembelajaran Creative Problem Solving terintegrasi TPACK yang dilakukan oleh guru dalam membelajarkan materi geometri dengan menggunakan kriteria kepraktisan yang telah ditetapkan sebelumnya. Berdasarkan data yang diperoleh dari lembar observasi yang telah dikumpulkan baik lembar observasi oleh para ahli maupun respon guru, disajikan seperti Tabel 7. 
Tabel 7. Hasil penilaian kepraktisan model yang dikembangkan oleh ahli

\begin{tabular}{lcl}
\hline Validator/Ahli & Tingkat Kepraktisan & Kategori \\
\hline Ahli pertama & 84 & Praktis \\
Ahli kedua & 82 & Praktis \\
Ahli ketiga & 82 & Praktis \\
Rata-rata & 82,67 & Praktis \\
\hline
\end{tabular}

Berdasarkan hasil validasi para ahli baik oleh ahli pertama, kedua dan ketiga serta rata-rata hasil dari validasi menunjukkan bahwa model pembelajaran Creative Problem Solving terintegrasi TPACK yang dikembangkan tergolong praktis. Kepraktisan produk berdasarkan keterlaksanaan pembelajaran yang dilakukan guru matematika menggunakan produk yang dikembangkan disajikan pada Tabel 8 .

Tabel 8. Hasil Penilaian Kepraktisan Produk yang Dilakukan oleh Observer

\begin{tabular}{lcccc}
\hline \multirow{2}{*}{\multicolumn{1}{c}{ Aspek Penilaian }} & \multicolumn{4}{c}{ Pertemuan } \\
\cline { 2 - 5 } & Pertama & Kedua & Ketiga & Keempat \\
\hline Penyampaian indikator pembelajaran & 85 & 81 & 82 & 84 \\
Memotivasi siswa & 83 & 86 & 81 & 82 \\
Masalah nyata & 82 & 84 & 79 & 74 \\
Penguasaan materi & 82 & 80 & 78 & 75 \\
Penguasaan teknologi & 78 & 81 & 81 & 79 \\
Ketepatan sintak pembelajaran & 79 & 75 & 76 & 78 \\
Integrasi teknologi & 81 & 78 & 79 & 82 \\
Melakukan evaluasi & 84 & 82 & 82 & 81 \\
Pengelolaan kelas & 85 & 83 & 78 & 78 \\
Merumuskan kesimpulan & 76 & 82 & 75 & 75 \\
Rata-rata skor & 81.5 & 81.2 & 79.1 & 78.8 \\
Kesimpulan & Praktis & Praktis & Paktis & Praktis \\
\hline
\end{tabular}

Mengacu pada skor yang ditunjukkan pada Tabel 8 di atas menunjukkan bahwa, penerapan pembelajaran dengan menggunakan model Creative problem Solving terintegrasi TPACK selama 4 kali pertemuan menunjukkan bahwa model pembelajaran yang digunakan dalam pembelajaran termasuk dalam kategori praktis baik pada pertemuan 1,2,3 dan pertemuan 4. Namun demikian, berdasarkan hasil pengamatan pada setiap pertemuan terdapat beberapa hal yang harus diperbaiki dalam pelaksanaan pembelajaran.

Pada pertemuan pertama, hasil pengamatan menunjukkan bahwa guru perlu melakukan perbaikan pada aspek 1) penguasaan teknologi yang digunakan perlu disesuaikan dengan materi yang dibelajarkan dan disarankan guru mensosialisaikan dulu sebelum digunakan dalam pembelajaran, 2) mencermati kembali urutan sintak pembelajaran sehingga pelaksanaan pembelajaran lebih sistematis dan mengikuti sintak yang sudah dirumuskan dalam rancangan pembelajaran, 3) dalam menarik kesimpulan, disarankan agar guru terlebih dahulu meminta siswa untuk mengambil kesimpulan dan guru mengarahkan bukan guru yang langsung menarik kesimpulan. Pada pertemuan kedua, hasil pengamatan menunjukkan bahwa penguasaan sintak pembelajaran masih belum sepenuhnya dikuasai guru, hal ini disebabkan penerapan pembelajaran berbasis Creative Problem Solving terintegrasi TPACK ini cenderung baru bagi guru dan disarankan agar lebih dipahami lagi sintak pembelajarannya. Disamping itu, integrasi teknologi yang dipilih dalam menggali konsep juga masih perlu diberdayagunakan.

Pada pertemuan ketiga, masalah nyata yang dipilih guru pada kegiatan awal perlu disesuaikan dengan materi yang dibelajarkan dan lebih menantang yang memerlukan berbagai strategi dalam penyelesaian. Selain itu, guru perlu penguasaan maateri baik materi esensial maupun advanced materi karena hal ini akan berpengaruh terhadap pengelolaan kelas yang dilakukan guru. Dalam penarikan kesimpulan, guru juga perlu meminta siswa untuk mengambil kesimpulan dan guru memberikan penguatan. Pada pertemuan keempat, hasil pengamatan terhadap pelaksanaan pembelajaran menunjukkan bahwa guru disarankan untuk melakukan refleksi dan perbaikan pada aspek 1) pemilihan 
masalah nyata, 2) penguasaan materi, 3) pemilihan dan integrasi teknologi dalam menngali konsep pada materi yang dibelajarkan, 4) pengelolaan kelas terutama ketika siswa melakukan diskusi kelompok, 5) menarik kesimpulan pada akhir pembelajaran.

\section{Efektivitas produk}

Efektivitas produk yang dikembangkan yaitu rancangan pembelajaran model Creative Problem Solving terintegrasi TPACK terlihat dari skor pretest dan postest tentang kemampuan siswa dalam memecahkan persoalan matematika pada materi geometri. Tes diberikan kepada siswa kelas VII Sekolah Menengah Pertama yang berjumlah 30 orang siswa. Skor hasil pretest dan postest kemampuan pemecahan masalah matematika siswa materi geometri ditunjukkan seperti pada Tabel 9.

Tabel 9. Skor pretest dan postes kemampuan pemecahan masalah siswa

\begin{tabular}{lcccccc}
\hline \multirow{2}{*}{ Indikator } & \multicolumn{3}{c}{$\begin{array}{c}\text { Rata-rata skor pemecahan } \\
\text { masalah siswa }\end{array}$} & Jumlah siswa & Persentase \\
\cline { 2 - 7 } & Pretest & Postest & N-Gain & $\begin{array}{c}\text { Tuntas } \\
\text { (Skor } \geq 75)\end{array}$ & $\begin{array}{c}\text { Tidak tuntas } \\
\text { Skor (<75) }\end{array}$ & $\begin{array}{c}\text { Siswa } \\
\text { Tuntas }\end{array}$ \\
\hline $\begin{array}{l}\text { Memahami masalah } \\
\begin{array}{l}\text { Menyusun strategi } \\
\text { penyelesaian }\end{array}\end{array}$ & 34.75 & 87.39 & 0.81 & & & \\
$\begin{array}{l}\text { Menyelesaikan } \\
\text { masalah }\end{array}$ & 34.84 & 86.67 & 0.79 & & & \\
$\begin{array}{l}\text { Memeriksa kembali } \\
\text { jawaban }\end{array}$ & 37.52 & 87.37 & 0.83 & 26 & 4 & 86.67 \\
Rata-rata skor & 36.28 & 87.66 & 0.81 & & & \\
\hline
\end{tabular}

Berdasarkan Tabel 9 di atas dapat dilihat bahwa dari 30 siswa kelas VII Sekolah Menengah Pertama yang diberikan tes tentang kemampuan siswa dalam pemecahan masalah matematika materi geometri terdapat 26 siswa atau $87.67 \%$ yang mendapatkan skor tes $\geq 75$ dan hanya 4 orang siswa yang tidak tuntas yaitu yang mendapat skor tes $<75$. Hal ini dapat disimpulkan bahwa persentase ketuntasan siswa dalam pembelajaran yaitu sebesar $87.67 \%$ memenuhi kriteria keterlaksanaan produk yang dikembangkan yaitu penerapan pembelajaran Creative Problem Solving terintegrasi TPACK minimal 85\%. Dengan demikian produk yang dikembangkan yaitu model pembelajaran Creative Problem Solving teintegrasi TPACK efektif untuk digunakan. Contoh penyelesaian soal gemetri siswa disajikan seperti pada Gambar 1.
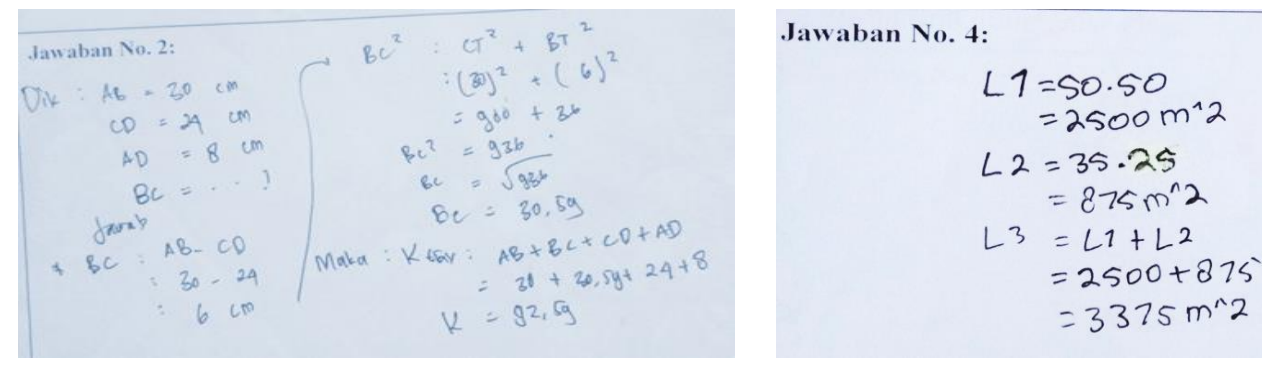

Gambar 1. Contoh jawaban penyelesaian masalah geometri siswa

Selanjutnya pengujian apakah model pembelajaran yang dikembangkan berpotensi dalam meningkatkan kemampuan siswa dalam memecahkan masalah pada materi geometri ditentukan berdasarkan nilai $N$-Gain yaitu perbedaan skor postes dan pretes kemampuan pemecahan masalah siswa materi geometri setelah melalui ujicoba penerapan pembelajaran berbasis Creative Problem Solving terintegrasi TPACK selama 4 kali pertemuam. Hasil ujicoba seperti disajikan pada Tabel 8 di atas menunjukkan bahwa nilai $\mathrm{N}$-Gain untuk aspek memahami masalah sebesar 0.81 termasuk kategori tinggi, aspek meyususn strategi penyelesaian sebesar 0,79 termasuk kategori tinggi, aspek menyelesaikan masalah sebesar 0.83 termasuk kategori tinggi dan aspek memeriksa kembali sebesar 
0.80 termasuk dalam kategori tinggi. Begitu pula jika dilihat nilai rata-rata dari 4 indikator pemecahan maslah diperoleh nilai $\mathrm{N}$-Gain sebesar 0.81 termasuk dalam kategori tinggi. Berdasarkan hal tersebut di atas, dapat dikatakan bahwa penerapan model pembelajaran Creative Problem Solving terintegrasi TPACK mempunyai potensi yang tinggi dalam meningkatkan kemampuan siswa dalam pemecahan masalah matematika khususnya pada materi geometri

Pembelajaran dengan model Creative Problem Solving terintegrasi TPACK dimulai dengan pemberian masalah nyata oleh guru yang harus diselesaikan siswa. Selanjutnya siswa diarahkan untuk menggali informasi terkait permasalahan yang diberikan guru dengan memanfaatkan teknologi seperti menggunakan android yang dimiliki untuk mendapatkan ide dan gagasan baru yang digunakan untuk menyelesaikan masalah tersebut melalui diskusi aktif baik dalam kelompok maupun antar kelompok. Diskusi dalam kelompok dimaksudkan agar siswa dapat menuangkan ide dan gagasan serta bereksperimen dalammenyelesaikan masalah, dan selanjutnya siswa mempresentasikan hasil penyelesaian masalah mereka. Rangkaian kegiatan mulai dari pemberian masalah sampai presentasi hasil penemuan atau pemecahan masalah, baik guru maupun siswa memanfaatkan teknologi informasi yang sesuai dengan setiap tahapan rangkaian kegiatan pembelajaran misalnya memanfaatkan laptop dan LCD untuk presentasi, aplikasi google drive untuk mengirim masalah nyata yang harus diselesaikan siswa serta android yang digunakan siswa untuk menggali berbagai informasi yang digunakan untuk menyelesaikan maslah tersebut. Rangkaian kegiatan pembelajaran yang dilakukan seperti ini diyakini mampu menumbuhkan kemampuan berpikir tingkat tinggi dan rasa ingin tahu siswa serta diyakini pula mampu meningkatkan kemampuan pemecahan masalahan matematika siswa. Proses pembelajaran yang melibatkan secara aktif siswa dalam pembelajaran dengan memanfaatkan berbagai sumber belajar yang sesuai dan memadai diharapkan mampu menciptakan rasa ingin tahu siswa (Andana, 2014). Penerapan pembelajaran model Creative Problem Solving terintegrasi TPACK memungkinkan siswa untuk berdiskusi secara berkelompok untuk mengembangkan kemampuan pemecahan masalah matematika. Pembelajaran dengan model Creative problem Solving terintegrasi TPACK memberikan kesempatan kepada siswa untuk menggali informasi, menemukan ide dan menemukan konsep yang dapat digunakan oleh siswa dalam penyelesaian masalah (Muhammad, 2018, p. 317).

Pemanfaatan teknologi yang sesuai dan tepat dalam pembelajaran sangat diperlukan dalam membelajarkan suatu materi tertentu. Dalam hal ini, guru dituntut mempunyai kompetensi untuk memastikan bahwa pemilihan dan penggunaan teknologi dalam pembelajaran yang dilakukan efektif. Disamping itu, guru juga dituntut memahami kapan teknologi yang dipilih tersebut digunakan dan bagaimana cara menggunakannya, mengantisipasi dampak yang ditimbulkan dari penggunaan teknologi dalam pembelajaran serta keefektifan teknologi yang digunakan dalam membelajarkan materi ajar tertentu dengan menggunankan strategi pembelajaran tertentu (Guerrero, 2010, p. 135). Integrasi teknologi, pedagogi dan konten dalam bentuk perangkat pembelajaran berbasis Technology, Pedagogy, and Content Knowledge (TPACK) sebagai solusi kreatif yang dikembangkan dalam pembelajaran (Sutrisno, 2012). Perangkat pembelajaran berbasis TPACK mengoptimalkan aktivitas pembelajaran siswa dan mampu meningkatkan keterampilan berpikir kritis dan pemecahan masalah siswa (Mairisiska, 2014, p. 36).

Integrasi TPACK dalam membelajarkan materi tertentu dalam pembelajaran mengacu pada kemampuan seorang guru untuk mengintegrasikan isi materi yang akan dibelajarkan ke dalam bentuk pembelajaran dengan kemampuan pedagogik guru yang memadai untuk berbagai kemampuan dan karakteristik siswa (Purwaningsih, 2015, p. 10). Dengan mengintegrasikan TPACK ketika seorang guru menerapkan pembelajaran Creative Problem Solving dalam membelajrkan materi ajar tertentu mempunyai potensi yang tinggi dalam mengembangkan dan meningkatkan kemampuan siswa dalam pemecahan masalah matematika yang diberikan guru. Disamping berdampak terhadap peningkatan kemampuan pemecahan masalah siswa, pengembangan model pembelajaran terintegrasi TPACK menggunakan model pembelajaran Creative Problem Solving juga diyakini berdampak terhadap peningkatan kemampuan berpikir tingkat tinggi siswa yaitu kemampuan berpikir kritis, kemampuan berpikir kreatif dan kemampuan komunikasi matematika siswa.

\section{SIMPULAN}

Produk yang dikembangkan berupa rancangan pembelajaran model Creative Problem Solving terintegrasi TPACK telah dikembangkan berdasarkan analisis kebutuhan dan dikembangkan dengan 
sistematis serta mengacu pada tahapan pengembangan model pembelajaran Borg \& Gall. Rancangan pembelajaran menggunakan model Creative Problem Solving terintegrasi TPACK yang dikembangkan, berdasarkan uji kevalidan, kepraktisan, dan keefektifan telah memenuhi kriteria yang telah ditetapkan. Hasil validasi oleh 3 ahli masing masing ahli dari segi bahasa, ahli di bidang materi, dan ahli di bidang teknologi pembelajaran menunjukkan bahwa produk yang dikembangkan termasuk dalam kategori valid dengan skor kevalidan berturut turut sebesar $80.0 ; 79.9$ dan 80.8 dan layak untuk dilanjutkan pada tahap uji coba lapangan. Berdasarkan penilaian kepraktisan yang dilakukan para ahi, produk berupa rancangan pembelajaran menggunakan model Creative Problem Solving terintegrasi TPACK juga memenuhi kategori kepraktisan dengan skor berturut turut sebesar 84, 82 dan 82. Begitu pula setelah dilakukan ujicoba di kelas selama 4 kali pertemuan, hasil pengamatan menunjukkan bahwa skor keterlaksanaan penerapan pembelajaran pada pertemuan 1,2 , 3 dan 4 berturut turut sebesar $81.5 ; 81.2 ; 79.1 ; 78.8$ termasuk dalam kategori paktis. Sementara itu, produk berupa rancangan pembelajaran menggunakan model Creative Problem Solving terintegrasi TPACK yang dikembangkan termasuk kategori efektif yang ditunjukkan oleh persentase jumlah siswa yang memperoleh skor kemampuan pemecahan masalah pada materi geometri $\geq 75$ sebesar $86.67 \%$, lebih tinggi dari indikator efektivitas yang ditetapkan yaitu sebesar $85 \%$. Model pembelajaran yang digunakan yaitu model Creative Problem Solving terintegrasi TPACK juga memiliki efek potensial yang tinggi dalam meningkatkan kemampuan siswa dalam pemecahan masalah matematika yang ditunjukkan oleh nilai $N$-Gain sebesar 0.81

Implikasi dari penelitian ini, dalam pembelajaran abad 21 saat ini guru tidak hanya sebagai penonton atas perkembangan teknologi tetapi guru juga diharapkan sebagai pelaku yang mampu menngunakan teknologi dalam pembelajaran. Di samping itu, guru juga diharapkan mampu menggunakan strategi pembelajaran inovatif yang berpusat pada siswa. Guru juga diharapkan mampu mengembangkan kemampuan berpikir kritis, kreatif dan kemampuan pemecahan masalah matematika dengan menerapkan model pembelajaran yang berpusat pada siswa terutama Creative Problem Solving terintegrasi TPACK.

\section{DAFTAR PUSTAKA}

Adams, J., Kaczmarczyk, S., Picton, P., \& Demian, P. (2010). Problem solving and creativity in engineering: Conclusions of a three year PBL project involving reusable learning objects and robots. International Conference on Engineering Education ICEE-2010, July 18-22, Gliwice, Poland. http://www.ineer.org/Events/ICEE2010/papers/M13C/Paper_953_1242.pdf

Akturk, A. O. \& Ozturk, H. S. (2019). Teachers TPACK levels and students self-efficacy as predictors of students academic achievement. International Journal of Research in Education and Science, 5(1), 283-294. https://www.ijres.net/index.php/ijres/article/view/543

Andana, E., Raga, G., \& Nyoman, S. (2014). Pengaruh model pembelajaran berbasis proyek terhadap hasil belajar IPA. Jurnal Mimbar PGSD Universitas Pendidikan Ganesha, 2(1), 25-29. http://dx.doi.org/10.23887/jjpgsd.v2i1.2490

Andayani, F., \& Lathifah, A. N. (2019). Analisis kemampuan pemecahan masalah siswa SMP dalam menyelesaikan soal pada materi aritmatika sosial. Jurnal Cendekia: Jurnal Pendidikan Matematika, 3(1), 1-10. https://doi.org/10.31004/cendekia.v3i1.78

Bahrudin, J. (2020). Penerapan model pembelajaran creatif problem solving untuk meningkatkan hasil belajar teknologi layanan jaringan materi ragam aplikasi komunikasi data. Journal of Education Action Research, 4(4), 536-545. http://dx.doi.org/10.23887/jear.v4i4.28924

Borg, W. R., \& Gall. (2007). Education research: An introduction. New York \& London: Logman.

Effendi, A., \& Fatimah, A. T. (2019). Implementasi model pembelajaran creative problem solving untuk siswa kelas awal sekolah menengah kejuruan. Jurnal Teorema: Teori dan Riset Matematika, 4(2), 89-98. http://dx.doi.org/10.25157/teorema.v4i2.2535

Endah, D. R. J., Kesumawati, N., \& Andinasari, A. (2019). Kemampuan pemecahan masalah matematis berdasarkan self efficacy siswa melalui Logan avenue problem solving-heuristic. JNPM (Jurnal Nasional Pendidikan Matematika), 3(2), 207-222. http://dx.doi.org/10.33603/jnpm.v3i2.2331 
Farikah, F., \& Firdaus, F. (2020). Technological Pedagogical and Content Knowledge (TPACK): The students' perspective on writing class. Jurnal Studi Guru dan Pembelajaran, 3(2), 190-197. https://doi.org/10.30605/jsgp.3.2.2020.303

Guerrero, S. (2010). Technological pedagogical content knowledge in the mathematics classroom. Journal of Digital Learning in Teacher Education, 26(4), 132-139. https://files.eric.ed.gov/fulltext/EJ893871.pdf

Hariawan, H., Kamaluddin, K., \& Wahyono, U. (2014). Pengaruh model pembelajaran creative problem solving terhadap kemampuan memecahkan masalah Fisika pada siswa kelas XI SMA Negeri 4 Palu. JPFT (Jurnal Pendidikan Fisika Tadulako Online), 1(2), 48. https://doi.org/10.22487/j25805924.2013.v1.i2.2395

Hidayat, W., \& Sariningsih, R. (2018). Kemampuan pemecahan masalah matematis dan adversity quotient siswa SMP melalui pembelajaran open ended. JNPM (Jurnal Nasional Pendidikan Matematika, 2(1), 109-118. http://dx.doi.org/10.33603/jnpm.v2i1.1027

Huda, M. (2014). Model-model pengajaran dan pembelajaran. Yogyakarta: Pustaka Pelajar.

Ismiyanto, I., Syafii, S., \& Syakir, S. (2010). Implementasi creative problem solving dalam pembelajaran menggambar: Upaya peningkatan kreativitas siswa sekolah dasar. Imajinasi Jurnal Seni, 6(2), 103-113. https://docplayer.info/36157904-Implementasi-creative-problemsolving-dalam-pembelajaran-menggambar-upaya-peningkatan-kreativitas-siswa-sekolahdasar.html

Karen L, Pepkins. 2004. Creative problem solving in math. https://rppsekolahdasar.blogspot.com

Khaulah, S. (2018). Penerapan model pembelajaran jucama dengan menggunakan blok aljabar untuk meningkatkan kemampuan berfikir kreatif siswa pada materi persamaan kuadrat. Jurnal Pendidikan Almuslim, 6(2), 75-83. http://jfkip.umuslim.ac.id/index.php/jupa/issue/view/52

Khatimah, H., \& Sugiman, S. (2019). The effect of problem solving approach to mathematics problem solving ability in fifth grade. In Journal of Physics: Conference Series, 1157(4), 1-7. https://iopscience.iop.org/article/10.1088/1742-6596/1157/4/042104/meta

Koehler, M. J., Mishra, P., \& Cain, W.(2013). What is technological pedagogical content knowledge. Journal of Education, 193(3), 13-19. https://www.learntechlib.org/p/159628

Mahmudi, A. (2009). Mengembangkan kemampuan berpikir kreatif siswa melalui pembelajaran topik pecahan. http://staffnew.uny.ac.id/upload/132240454

Maimunah, M., Purwanto, P., Sa'dijah, C., \& Sisworo, S. (2016). Penerapan model pembelajaran matematika melalui pemecahan masalah untuk meningkatkan penalaran matematis siswa kelas X-A SMA AL-Musilum. Jurnal Review Pembelajaran Matematika, 1(1), 17-30. https://doi.org/10.15642/jrpm.2016

Mairisiska, T., Sutrisno, S., \& Asrial, A. (2014). Pengembangan perangkat pembelajaran berbasis TPACK pada materi sifat koligatif larutan untuk meningkatkan keterampilan berpikir kritis siswa. Edu Sains, 3(1), 28- 37. https://doi.org/10.22437/jmpmipa.v3i1.1764

Malik, S., Rohendi, D., \& Widiaty, I. (2018). Technological Pedagogical Content Knowledge (TPACK) with information and Communication Technology (ICT) integration: A literature review. Advances in Social Science, Education and Humanities Research, 299, 498-503. https://doi.org/10.2991/ictvet-18.2019.114

Manurung, S. L. (2015). Peningkatan kemampuan berpikir kritis siswa melalui penerapan model pembelajaran creative problem solving (CPS) dengan menggunakan software autograph. Jurnal Handayani, 4(2), 1-8. https://doi.org/10.24114/jh.v4i2.2845

Mishra, P., \& Koehler, M. J. (2006).Technological pedagogical content knowledge: A framework for teacher knowledge. Teachers College Record, 108(6), 1017-1054. https://www.learntechlib.org/p/99246/ 


\section{Jurnal Riset Pendidikan Matematika, 8(2), 2021 - 204}

Edy Waluyo, Nuraini

Mullis, I. V. S., Martin, M. O., Foy, P., \& Hooper, M. (2016). TIMSS 2015 international results in mathematics. Retrieved from Boston College, TIMSS \& PIRLS International Study Center. http://timssandpirls.bc.edu/timss2015/international-results/

Muhammad, G., M., Septian, A., \& Sofa, M. I. (2018). Penggunaan model pembelajaran creative problem solving untuk meningkatkan kemampuan pemecahan masalah matematis siswa. Jurnal Mosharafa, 7(3), 315-325. https://doi.org/10.31980/mosharafa.v7i3.140

Muslich, M. (2007). KTSP pembelajaran berbasis kompetensi dan kontekstual. Jakarta: Bumi Aksara.

National Council of Teachers of Mathematics. (2000). Principles and standards for school mathematics. Reston, VA: The National Council of Teachers of Mathematics. www.nctm.org

Nur, I., Udiyah, M., \& Pujiastutik, H. (2017). Implementation of Creative Problem Solving (CPS) to the problem solving ability IPA class VII SMP Negeri 2 Tuban. Proceeding Biology Education Conference, 14(1), 540-544. https://jurnal.uns.ac.id/prosbi/article/view/21092

Nur, A., S., \& Markus. P. M. (2018). Profil kemampuan pemecahan masalah matematika siswa ditinjau dari perbedaan gaya kognitif dan gender. Kreano: Jurnal Matematika Kreatif-Inovatif, 9(2), 139-148. http://dx.doi.org/10.15294/kreano.v9i2.15067

Nursiami, S., \& Soeprodjo, S. (2015). Keefektifan model pembelajaran creative problem solving berbantuan flash interaktif terhadap hasil belajar. Jurnal Inovasi Pendidikan Kimia, 9(1), 14401449. https://journal.unnes.ac.id/nju/index.php/JIPK/article/view/4811

OECD. (2016). PISA 2015 assessment and analytical framework: science, reading, mathematics and financial literacy. Paris, France: OECD Publishing. http://dx.doi.org/10.1787/9789264255425en

Paryanto, A., \& Kurniasih, N. (2020). Eksperimentasi model pembelajaran kooperatif rotating trio exchange (RTE) dan means ends analysis (MEA) terhadap hasil belajar siswa kelas VIII SMPN 10 Purworejo tahun pelajaran 2019/2020. Jurnal Prosiding Sendika, 6(2), 55-61. http://eproceedings.umpwr.ac.id/index.php/sendika/article/download/1195/1002

Pepkin, K. L. (2004). Creative problem solving in math. http://-www.uh.edu/hti/cu/2004/v02/04.htm

Pramestika, R. A., Suwignyo, H., \& Utaya, S. (2020). Model pembelajaran creative problem solving pada kemampuan berpikir kreatif dan hasil belajar tematik siswa sekolah dasar. Jurnal Pendidikan, 5(3), 361-366. https://doi.org/http://dx.doi.org/10.17977/jptpp.v5i3.13263

Puccio, G. J., Mary C. M., \& Marie, M. (2005). Current developments in creative problem solving for organizations: A focus in thinking skills and styles. The Korean Journal of Thinking and Problem Solving, 15(2), 43-76. https://tsf.njit.edu/sites/tsf/files/lcms/2006/fall/puccio-koreanjournal.pdf

Purwaningsih E. (2015). Potret representasi pedagogical content knowledge (PCK) guru dalam mengajarkan materi getaran dan gelombang pada siswa SMP, Indonesian Journal of Applied Physics, 5(1), 9-15. https://doi.org/10.13057/ijap.v5i01.252

Rahmani, W. Widyasari. (2018). Meningkatkan kemampuan pemecahan masalah matematis siswa melalui media tangram. Fibonacci, 4(1), 17-24. https://doi.org/10.24853/fbc.4.1.17-24

Rahmadi, I. F., Hayati, E., \& Nursyifa, A. (2020). Comparing pre-service civic education teachers' tpack confidence across course modes: Insights for future teacher education programs. Research in Social Sciences and Technology, 5(2), 113-133. http://10.46303/ressat.05.02.7

Septian, A. (2019). Pembelajaran dengan model Creative Problem Solving (CPS) untuk meningkatkan kemampuan berpikir kreatif matematis siswa. Prisma, 8(2), 182-190. https://doi.org/10.35194/jp.v8i2.376

Siswono, T. Y. E. (2008). Proses berfikir kreatif siswa dalam memecahkan dan mengajukan masalah matematika. Jurnal Ilmu Pendidikan, 15(1), 60-68. http://dx.doi.org/10.17977/jip.v15i1.13 
Sugianto, P. A. W. (2019). Penerapan model pembelajaran vps dengan bantuan modul elektronik terhadap motivasi belajar dan kempuan berpikir kreatif di SMA Negeri 8 Pekan Baru 2017. Journal of Chemical Information and Modeling, 53(9), 1689-1699. https://doi.org/10.1017/CBO9781107415324.004

Sutrisno, S. (2012). Kreatif mengembangkan aktivitas pembelajaran berbasis TIK. Jakarta, Indonesia: Gaung Persada.

Tuithof, H., van Drie, J., Bronkhorst, L., Dorsman, L., \& Van Tartwijk, J. (2021). Teachers' pedagogical content knowledge of two specific historical contexts captured and compared. Educational Studies, 47(2), 1-26, https://doi.org/10.1080/03055698.2021.1877621

Turmuzi, M., Azmi, S., \& Hikmah, N. (2018). Penerapan model pembelajaran Creative Problem Solving (CPS) Untuk meningkatkan kemampuan pemecahan masalah mahasiswa pendidikan matematika. J. Pijar MIPA, 1(1), 45-50. https://doi.org/10.29303/jpm

Ulya, H. (2016). Profil kemampuan pemecahan masalah siswa bermotivasi belajar tinggi berdasarkan ideal problem solving. Jurnal Konseling Gusjigang, 2(1), 90-96. https://doi.org/10.24176/jkg.v2i1.561

Waluyo, E., Supiyati, S., \& Halqi, M. (2020). Mengembangkan perangkat pembelajaran kalkulus integral berbasis model pengajuan dan pemecahan masalah untuk meningkatkan kemampuan berpikir kreatif mahasiswa. Jurnal Elemen, 6(2), 357- 366. http://10.29408/jel.v6i2.23344

Winarti, W. (2017). Kemampuan pemecahan masalah siswa dalam menyelesaikan soal cerita berdasarkan gaya belajar pada materi pecahan di SMP. Jurnal Pendidikan dan Pembelajaran, 6(6), 1-9. https://jurnal.untan.ac.id/index.php/jpdpb/article/view/20462/16773

Yanti, M., Sudia, M., \& Arapu, L. (2019). Pengaruh model pembelajaran mind mapping terhadap kemampuan berpikir kreatif matematis peserta didik kelas VIII SMP Negeri 8 Konawe Selatan. $\begin{array}{llll}\text { Jurnal Penelitian } & \text { Pendidikan }\end{array}$ http://dx.doi.org/10.36709/jppm.v7i3.11375 